\title{
KOMUNIKASI INTERPERSONAL MELALUI PENGGUNAAN MEDIA SOSIAL ANTARA DOKTER DAN PASIEN DI KLINIK MEDIKA LESTARI JAKARTA
}

Oleh :

\section{SATYA CANDRASARI}

\author{
Program Studi Ilmu Komunikasi Fakultas Industri Kreatif \\ Institut Teknologi dan Bisnis Kalbis Jakarta
}

\begin{abstract}
This research analyze in more detail the interpersonal communication between doctor and patient through social media at Medika Lestari Clinic. The role of social media is expected to be a central tool in order to improve health in the society. Interpersonal communication is key in order to provide health information for both patients and doctors or other medical personnel. Interpersonal communication that will be discussed is about the positive aspects that would have a significant impact for the progress of health services to the community. This research will take place at the Medika Lestari Clinic in Rawasari area. From this study it was concluded that interpersonal communication through social media Whatsapp between doctors and patients is very considering openness, empathy, supportive attitude, positive attitude, and equality.
\end{abstract}

Keywords: communication, interpersonal communication, social media (whatsapp), medika lestari clinic

\section{PENDAHULUAN}

Kesehatan dan teknologi adalah dua hal yang tidak dapat dipisahkan. Dua hal ini seperti halnya sekeping mata uang dengan dua gambar berbeda namun tujuannya sama. Kesehatan dan teknologi merupakan dua hal yang berbeda secara definisi, namun ketika dua hal ini disatukan maka dapat memiliki tujuan yang sama yakni untuk kehidupan yang lebih baik. Pada era paska modern seperti ini, teknologi menjelma dalam beberapa bentuk di segala aspek kehidupan, tidak terkecuali dengan teknologi kesehatan. Teknologi seharusnya mendukung terciptanya kualitas unggul dari kesehatan dalam masyarakat.

Teknologi sendiri dalam konteks kesehatan dapat dibagi menjadi dua perspektif. Persepektif pertama adalah perspektif dari tenaga kesehatan dan perspektif kedua adalah perspektif dari pasien. Bagi tenaga kesehatan, teknologi merupakan sarana untuk dapat semakin mengefektifkan pekerjaannya. Penggunaan teknologi dalam kesehatan akan membawa pemahaman yang lebih tepat dan detail mengenai jenis penyakit dan hal-hal yang berhubungan dengan kesehatan. Sedangkan bagi pasien, teknologi berarti efisiensi. Efisiensi di sini diartikan sebagai kecepatan pasien dalam menerima informasi baik dari tenaga medis/kesehatan maupun dari institusi kesehatan mengenai keadaan kesehatannya atau mengenai ketersediaan layanan kesehatan yang ditawarkan.

Walaupun teknologi kesehatan sudah berkembang pesat, namun ada satu fenomena yang cukup menyedihkan. Fenomena yang menyedihkan ini muncul di Indonesia, ketika tidak semua lapisan masyarakat dapat menikmati kesehatan secara merata dengan kualitas yang sama. 
Setidaknya fenomena ini terjadi di sebagian besar wilayah Indonesia bahkan di pulau Jawa. Jika dilihat dengan angka yang lebih presisi, Indonesia memiliki 9.655 Puskesmas dengan penyebaran terbanyak di wilayah Jawa (Nugroho, 2017:10). Jakarta sebagai ibu kota seharusnya memiliki cukup Puskesmas untuk melayani kebutuhan masyarakat. Namun dari data yang ada 50.704 orang yang meninggal pada tahun 2016 (BPS, 2018). Data jumlah penduduk di DKI Jakarta pada tahun yang sama adalah sebesar 9.607.787 yang berarti jumlah persentase kematian di Jakarta sebesar 0,52\% (BPS, 2018). Dari besarnya jumlah kematian tersebut, ada kemungkinan bahwa salah satu penyebab kematian adalah waktu penanganan pasien yang terlalu bertele-tele karena keterbatasan teknologi pemindai cepat atau pasien tidak mendapatkan informasi yang tepat terkait penyakit yang dihadapinya. Teknologi dewasa ini selalu dikaitkan dengan teknologi internet. Penggunaan internet yang tepat akan sangat dibutuhkan dan membantu bagi dunia kesehatan.

Fakta menunjukkan bahwa ada 132,7 juta orang menggunakan internet melalui gawai mereka. Ada 86,3 juta orang yang menggunakannya di pulau Jawa, angka itu sekitar $65 \%$ dari total populasi yang menggunakan internet. Menurut data tersebut, dapat disimpulkan bahwa ada peluang yang besar untuk pemanfaatan teknologi informasi untuk kesehatan yang dilihat dari penetrasi pengguna internet di wilayah Jawa. Pemanfaatan ini dapat meningkatkan peluang hidup bagi masyarakat di wilayah Jawa khususnya Jakarta. Pemanfaatan teknologi dalam rangka meningkatkan peluang hidup melalui komunikasi teknologi ini menjadi peluang sekaligus tantangan bagi peneliti untuk dapat menemukan jawaban yang baik dan benar dalam rangka meningkatkan kualitas kehidupan dalam masyarakat.

Aspek manusia yang berada di belakang gawai juga merupakan aspek kunci sekaligus sebagai aspek yang tak terpisahkan dari manfaat dan fungsi gawai itu sendiri yakni berkomunikasi. Komunikasi melalui media teknologi internet baru semarak muncul tidak lebih dari 15 tahun lalu. Perkembangan teknologi yang begitu pesat membawa dampak yang terpolarisasi yakni baik dan buruk. Dampak baik dari teknologi internet adalah adanya komunikasi yang semakin intens antara manusia-manusia baik di sekitar maupun di tempat yang jauh. Komunikasi intens ini ditambah nilainya dengan kemampuan gawai yang semakin canggih yang dapat mengirimkan kondisi riil pada saat itu juga. Dampak buruknya adalah penyelewengan kegunaan internet untuk hal-hal yang tidak pantas atau bahkan kejahatan. Kesemua dampak itu hadir dan diciptakan oleh manusia yang notabene adalah aktor atau subyek di belakang alat (gawai).

Seandainya dampak positif dari internet ini, seperti komunikasi intens antara pasien dan dokter, digunakan semaksimal mungkin, maka kemungkinan besar angka kematian atau jumlah pasien akan menurun. Angka kematian akan menurun karena penanganan pertama pada korban atau pasien dapat dilakukan secara mandiri dengan bantuan arahan dari dokter atau tenaga medis yang bersangkutan melalui media sosial. Sedangkan untuk penurunan jumlah pasien disebabkan oleh sosialisasi kesehatan yang memberikan informasi mengenai cara hidup sehat oleh dokter atau tenaga medis kepada masyarakat sekitar juga melalui media sosial.

Ardianto dalam buku Komunikasi 2.0 mengungkapkan, bahwa media sosial daring, disebut jejaring sosial daring bukan media massa daring karena media sosial memiliki kekuatan sosial yang sangat mempengaruhi opini publik yang berkembang di masyarakat. Penggalangan dukungan atau gerakan massa bisa terbentuk karena kekuatan media daring karena apa yang ada di dalam media sosial, terbukti mampu membentuk opini, sikap 
dan perilaku publik atau masyarakat. Fenomena media sosial ini bisa dilihat dari kasus Prita Mulyasari versus Rumah Sakit Omni International. Inilah alasan mengapa media ini disebut media sosial bukan media massa. (Ardianto, 2011: xii)

Ada beberapa aplikasi yang sudah ada di google play yang memberikan dukungan baik kepada pasien maupun kepada dokter dalam upaya mengkomunikasikan kondisi kesehatan dan tindak lanjut yang diperlukan. Namun, tanpa aplikasi itupun seharusnya pasien dan dokter dapat melakukan komunikasi menggunakan aplikasi media sosial yang ada seperti Line atau Whatsapp. Komunikasi interpersonal sangat dibutuhkan di sini, sehingga dalam keadaan yang memerlukan bantuan segera, kerabat atau teman pasien dapat melakukan tindakan yang perlu untuk melakukan pertolongan pertama pada pasien. Komunikasi interpersonal yang efektif dan efisien yang menjadi kekuatan utama dari keberhasilan penggunaan media sosial dalam konteks kesehatan.

Penelitian kali ini akan lebih fokus pada media teknologi komunikasi yang digunakan oleh pasien dalam rangka berkomunikasi dengan tenaga medis atau kesehatan dalam hal ini dokter. Komunikasi ini dinilai oleh peneliti lebih banyak bermafaat bagi lebih banyak orang. Komunikasi interpersonal dengan menggunakan media teknologi komunikasi melalui gawai menawarkan kebaikan terutama untuk bidang kesehatan. Menurut Kathleen S. Verderber dalam (Afriyadi, 2015:362), komunikasi interpersonal adalah proses melalui mana orang menciptakan dan mengelola hubungan mereka, melaksanakan tanggung jawab secara timbal balik dalam menciptakan makna. Unsur-unsur tambahan di dalam proses komunikasi antar pribadi adalah pesan dan isyarat perilaku verbal. Sedangkan komunikasi kesehatan antara dokter dan pasien atau sebaliknya adalah proses komunikasi yang melibatkan pesan kesehatan dan hal-hal yang menyangkut kesehatan. Komunikasi yang dibangun dengan baik antara dokter sebagai tenaga medis/kesehatan dan pasien dapat menjadi salah satu kunci keberhasilan dokter atau tenaga medis/kesehatan dalam memberikan upaya pelayanan medis.

Setidaknya ada tiga tujuan dari komunikasi interpersonal antara dokter sebagai tenaga medis atau kesehatan dengan pasien. Tujuan pertama adalah untuk menciptakan hubungan interpersonal yang baik antara dokter dan pasien. Tujuan kedua adalah untuk melakukan pertukaran informasi terkait dengan hal-hal kesehatan dan tujuan yang terakhir adalah untuk mengambil keputusan bagi dokter dan pasien terkait dengan kesehatan. Pada tujuan terakhir inilah tujuan tertinggi dari komunikasi kesehatan ini. Namun tidak dipungkiri bahwa tujuan yang pertama dan kedua adalah tujuan antara yang tidak dapat dianggap remeh.

Bentuk kongkrit dari komunikasi interpersonal yang berhubungan dengan kesehatan ini adalah aplikasi sosial media. Peneliti akan mencoba untuk menggali lebih dalam efektivitas dan efisiensi dari sosial media (Whatsapp) yang digunakan oleh pasien dan dokter langganan dalam rangka diagnosis awal penyakit dari pasien. Selama ini yang dilakukan adalah bahwa pasien memberitahukan gejala dan masalah kesehatan yang dialami menggunakan aplikasi yang ada. Hasil dari aplikasi tersebut kemudian dikonsultasikan kepada dokter langganan. Jika memang diperlukan diagnosis lebih lanjut maka pasien harus datang ke Klinik Medika Lestari ini. Namun, jika tidak diperlukan diagnosis lebih lanjut maka pasien dapat menerima anjuran obat yang ditawarkan oleh dokter di klinik ini. Ada banyak celah masalah dan juga prosedur yang diterapkan. Oleh karena itu peneliti melihat penelitian ini perlu diperdalam untuk menentukan lebih rinci dan jeluk/dalam baik konsep, proses maupun hasil dari e-Diagnosis ini. Penelitian ini lebih akan membahas mengenai konsep, proses dan hasil (output) dari eDiagnosis 
itu sendiri terhadap efektivitas dan efisiensi informasi yang didapatkan. Dari penjelasan latar belakang tersebut di atas, maka peneliti ingin melakukan penelitian dengan judul: "Komunikasi Interpersonal Melalui Penggunaan Media Sosial Antara Dokter dan Pasien di Klinik Medika Lestari”.

\section{METODE PENELITIAN}

Penelitian ini bertujuan untuk mengetahui sejauh mana komunikasi interpersonal melalui penggunaan media sosial antara dokter dan pasien di klinik Medika Lestari berlangsung.

Pendekatan dari penelitian ini adalah pendekatan kualitatif. Dengan menggunakan metode kualitatif, peneliti akan dapat menentukan cara mencari, mengumpulkan, mengolah dan menganalisis hasil dari data yang sudah didapatkan. Penelitian kualitatif dapat digunakan untuk memahami interaksi sosial dengan cara mewawancarai sumber secara mendalam sehingga dapat ditemukan pola-pola yang jelas. Penelitian kualitatif juga memberikan ruang kepada sebuah hal-hal yang tidak bisa diteliti pada metode kuantitatif seperti misalnya keterangan detail dan terperinci dari narasumber yang dapat menjadi kunci temuan-temuan pada sebuah penelitian.

\section{Jenis Penelitian}

Secara teoritis format penelitian kualitatif berbeda dengan format penelitian kuantitatif. Perbedaan tersebut terletak pada kesulitan dalam membuat desain penelitian kualitatif, karena pada umumnya penelitian kualitatif yang tidak berpola. Format desain penelitian kualitatif terdiri dari tiga model, yaitu format deskriptif, format verifikasi, dan format grounded research. Dalam penelitian ini digunakan metode kualitatif dengan desain deskriptif, yaitu penelitian yang memberi gambaran secara cermat mengenai individu atau kelompok tertentu tentang keadaan dan gejala yang terjadi (Koentjaraningrat, 1993:89).
Pada tahap berikutnya, peneliti akan memberikan gambaran dengan secara cermat tentang fenomena yang terjadi mengenai proses komunikasi interpersonal antara dokter dan pasien di Klinik Medika Lestari. Penelitian kualitatif menurut Moleong (2007:6) adalah penelitian yang bermaksud untuk memahami fenomena tentang apa yang dialami oleh subjek penelitian misalnya perilaku, persepsi, motivasi, tindakan, dll., secara holistik, dan dengan cara deskripsi dalam bentuk kata-kata dan bahasa, pada suatu konteks khusus yang alamiah dan dengan memanfaatkan berbagai metode alamiah.

Menurut Bogdan dan Taylor (1975) yang dikutip oleh Moleong (2007:4) mengemukakan bahwa metodologi kualitatif sebagai prosedur penelitian yang menghasilkan data deskriptif berupa katakata tertulis atau lisan dari orang-orang dan perilaku yang dapat diamati. Selanjutnya dijelaskan oleh David Williams (1995) seperti yang dikutip Moleong (2007:5) mengemukakan bahwa penelitian kualitatif adalah pengumpulan data pada suatu latar alamiah, dengan menggunakan metode alamiah, dan dilakukan oleh orang atau peneliti yang tertarik secara alamiah. Penelitian kualitatif bertujuan memperoleh gambaran seutuhnya mengenai suatu hal menurut pandangan manusia yang diteliti. Penelitian kualitatif berhubungan dengan ide, persepsi, pendapat atau kepercayaan orang yang diteliti dan kesemuanya tidak dapat diukur dengan angka.

\section{Informan Penelitian}

Dalam penelitian kualitatif, hal yang menjadi bahan pertimbangan utama dalam pengumpulan data adalah pemilihan informan. Teknik sampling yang digunakan oleh peneliti adalah purposive sample. Selanjutnya menurut Arikunto (2010:183) pemilihan sampel secara purposive pada penelitian ini akan berpedoman pada syarat-syarat yang harus dipenuhi sebagai berikut: 
a. Pengambilan sampel harus didasarkan atas ciri-ciri, sifat-sifat atau karakteristik tertentu, yang merupakan ciri-ciri pokok populasi.

b. Subjek yang diambil sebagai sampel benar-benar merupakan subjek yang paling banyak mengandung ciri-ciri yang terdapat pada populasi (key subjects).

c. Penentuan karakteristik populasi dilakukan dengan cermat di dalam studi pendahuluan. Seperti yang telah disebutkan bahwa pemilihan informan pertama merupakan hal yang sangat utama sehingga harus dilakukan secara cermat, karena penelitian ini mengkaji tentang proses komunikasi interpersonal antara dokter dan pasien di Klinik Medika Lestari, maka peneliti memutuskan informan pertama atau informan kunci yang paling sesuai dan tepat ialah Dokter kepala Klinik dalam hal ini dr. Diana dan Pasiennya.

Dari informan kunci ini selanjutnya diminta untuk memberikan rekomendasi untuk memilih informan-informan berikutnya, dengan catatan informaninforman tersebut merasakan dan menilai kondisi lingkungan kerja sehingga terjadi sinkronisasi dan validasi data yang didapatkan dari informan pertama. Berdasarkan atas rekomendasi kepala Klinik Medika Lestari, peneliti dapat mewawancarai satu orang dokter yang bekerja di Klinik Medika Lestari. Selain dari narasumber dokter, peneliti juga akan mewawancarai dua orang pasien yang menjadi pelanggan di Klinik Medika Lestari. Dari penjelasan mengenai narasumber tersebut, total responden yang akan diwawancarai ada tiga orang.

\section{Teknik Pengumpulan Data}

Pada penelitian ini peneliti menggunakan teknik pengumpulan data dengan cara observasi, dokumentasi, dan wawancara.

\section{Teknik Analisis Data}

Analisis data dimulai dengan melakukan wawancara mendalam dengan informan kunci, yaitu seseorang yang benar-benar memahami dan mengetahui situasi obyek penelitian. Setelah melakukan wawancara, analisis data dimulai dengan membuat transkrip hasil wawancara, dengan cara memutar kembali rekaman hasil wawancara, mendengarkan dengan seksama, kemudian menuliskan kata-kata yang didengar sesuai dengan apa yang ada direkaman tersebut.

Setelah peneliti menulis hasil wawancara tersebut kedalam transkrip, selanjutnya peneliti harus membaca secara cermat untuk kemudian dilakukan reduksi data. Peneliti membuat reduksi data dengan cara membuat abstraksi, yaitu mengambil dan mencatat informasiinformasi yang bermanfaat sesuai dengan konteks penelitian atau mengabaikan katakata yang tidak perlu sehingga didapatkan inti kalimatnya saja, tetapi bahasanya sesuai dengan bahasa informan.

Abstraksi yang sudah dibuat dalam bentuk satuan-satuan yang kemudian dikelompokkan dengan berdasarkan taksonomi dari domain penelitian. Analisis Domain menurut Sugiyono (2013:255), adalah memperoleh gambaran yang umum dan menyeluruh dari obyek/penelitian atau situasi sosial. Peneliti memperoleh domain ini dengan cara melakukan pertanyaan grand dan minitour. Sementara itu, domain sangat penting bagi peneliti, karena sebagai pijakan untuk penelitian selanjutnya. Mengenai analisis taksonomi yaitu dengan memilih domain kemudian dijabarkan menjadi lebih terinci, sehingga dapat diketahui struktur internalnya.

\section{HASIL PENELITIAN DAN PEMBAHASAN}

Komunikasi menjadi suatu unsur yang mendasar yang harus ditanamkan pada setiap orang. Komunikasi menjadi informasi dalam kehidupan sehari-hari. Komunikasi tidak hanya dilakukan untuk interaksi saja, tetapi komunikasi juga dapat 
untuk membangkitkan hal-hal positif seperti memotivasi seseorang. Komunikasi yang baik adalah komunikasi atau pesan atau informasi yang disampaikan dari seorang komunikator kepada seorang komunikan untuk mendapatkan umpan balik dari komunikan. Dengan adanya umpan balik maka komunikator akan mengetahui seberapa efektif informasi yang disampaikan kepada komunikan. Seorang komunikator dalam komunikasi interpersonal bisa diperankan oleh seorang dokter dan komunikan diperankan oleh seorang pasien maupun keluarga pasien.

Komunikasi interpersonal ini memiliki beberapa tujuan diantaranya adalah untuk membantu dokter dalam memberikan solusi atas pertanyaan-pertanyaan pasien seputar masalah kesehatan. Adapun tujuan lain pada komunikasi ini adalah untuk mencapai kesembuhan pasien. Komunikasi antara dokter dan pasien juga diharapkan dapat menjalin kerjasama dengan membangkitkan motivasi-motivasi seputar semangat untuk kesembuhan pasien. Komunikasi interpersonal yang baik adalah komunikasi yang efektif dimana tujuan yang direncanakan oleh dokter maupun pasien dapat terwujud secara bersamaan.

Perkembangan teknologi yang ditandai munculnya berbagai alat canggih, kemudahan dan kecepatan akses informasi serta komunikasi terjadi di segala aspek kehidupan masyarakat termasuk aspek kedokteran. Munculnya web 2.0 memudahkan penyebarluasan informasi oleh admin maupun pengguna. Salah satunya adalah munculnya media sosial yang dapat diakses oleh siapa saja, termasuk dokter dan pasien. Fleksibilias dan keterbukaan penggunaan media sosial menyebabkan pergeseran makna 'kontrak terapeutik' antara dokter dan pasien.

Kebebasan interaksi antara dokter pasien mulai dari masalah personal hingga konsultasi masalah kesehatan dapat dilakukan melalui media sosial seperti facebook, twitter, atau Whatsapp dengan mudah dan cepat. Seorang dokter seharusnya berpijak pada kaidah dasar bioetika sebagai prinsip dasar hubungan dokter-pasien. Hubungan dokter-pasien melalui media sosial memberikan efek yang menguntungkan bagi dokter dan pasien, dengan syarat terdapat aturan terlentu yang harus disepakati bersama.

Klinik Medika Lestari yang sudah beroperasi selama sembilan tahun ini telah mendapatkan kepercayaan dari masyarakat sekitarnya, terbukti dengan banyaknya pasien yang berobat di Klinik Medika Lestari, sedikitnya dalam satu hari pasien yang datang untuk berobat ada sepuluh orang. Perkembangan teknologi dan kebebasan berinteraksi antara dokter dan pasien dapat dilihat dari program Klinik Medika Lestari yaitu melakukan konsultasi kesehatan melalui media sosial yaitu Whatsapp. Konsultasi kesehatan melalui media sosial Whatsapp ini adalah fasilitas yang diberikan Klinik Medika Lestari kepada para pasiennya yang sudah pernah terdaftar menjadi pasien atau sudah pernah berobat di klinik tersebut. Fasilitas tersebut diberikan tanpa pungutan biaya tambahan tiap melakukan konsultasi melalui Whatsapp.

Kita dapat melihat bahwa proses komunikasi yang dilakukan oleh dokter kepada pasien efektif karena mencakup beberapa hal di bawah ini:

\section{a. Keterbukaan (Openness)}

Keterbukaan memiliki pengertian bahwa dalam komunikasi antar pribadi yang efektif, individu harus terbuka pada permasalahan atau penyakit yang diderita atau setidaknya riwayat penyakit yang dideritanya. Pasien harus berani membuka diri akan keluhan-keluhan dan masalah yang muncul. Agar komunikasi interpersonal yang dilakukan menghasilkan hubungan interpersonal yang efektif dan kerjasama dapat ditingkatkan, maka perlulah sikap keterbukaan tersebut.

Sapaan bisa digunakan sebagai pengungkapan diri dokter kepada pasien untuk menciptakan hubungan 
baik diantara mereka. Sementara memberi pasien kesempatan bertanya bisa digunakan sebagai reaksi spontan dokter untuk mengungkapkan sikap terbuka. Sehingga, untuk meningkatkan keterbukaan ketika berkomunikasi, para dokter di program Konsultasi Gratis melalui Whaatsapp sebaiknya meningkatkan kedua poin tersebut.

b. Empati (Empathy)

Empati adalah kemampuan seseorang untuk menempatkan dirinya pada posisi atau peranan orang lain. Artinya adalah bahwa seseorang secara emosional maupun intelektual mampu memahami apa yang dirasakan dan dialami oleh orang lain.

Kepercayaan pasien bisa didapatkan melalui empati yang ditunjukkan oleh dokter, salah satunya lewat komunikasi nonverbal, seperti misalnya kontak mata. Sebab selain mulut, tindakan dan mata manusia bisa mengatakan apa yang seseorang pikir dan rasakan. Selain kontak mata, komunikasi nonverbal juga bisa melalui sentuhan contohnya seperti berjabat tangan. Komunikasi nonverbal lainnya adalah penggunaan tinggi-rendah nada bicara pada setiap kalimat yang diucapkan oleh dokter. Dokter berempati dengan cara memberikan perhatian khusus bagi pasien yang berkonsultasi memalaui Whatsapp, dokter bertanya mengenai keluhan-keluhan pasien, gejala-gejala yang dirasakan pasien, pertolongan pertama apa yang telah diberikan sebelum melakukan konsultasi, dan memberikan solusi terhadap penyakit yang diderita pasien bahkan memberikan resep obat kepada pasien.

\section{c. Sikap Mendukung (Supportiveness)}

Komunikasi interpersonal akan efektif apabila dalam diri seseorang ada perilaku dengan sikap mendukung. Maksud dari hal ini adalah bahwa masing-masing subyek komunikasi saling memberikan dukungan terhadap pesan yang disampaikan. Sikap mendukung di sini dimaksudkan sebagai sikap yang kooperatif dalam berkomunikasi, mengurangi sikap defensive seperti ketakutan, kecemasan dan lain sebagainya yang menyebabkan komunikasi interpersonal akan gagal, karena orang dengan jenis defensive akan cenderung melindungi diri dari ancaman yang ditanggapi dalam komunikasi dibandingkan memahami orang lain. Sikap mendukung dokter kepada pasien bisa ditunjukkan melalui banyak cara, antara lain menjawab pertanyaan dan mengajak pasien berdiskusi. Selain memberikan pertanyaan seputar keluhan pasien, dokter juga sebaiknya memberikan penjelasan sesuai pertanyaan yang diajukan pasien. Sebab, setiap pertanyaan yang dijawab akan membantu pasien dalam memahami keluhan atau ketidaktahuannya. Selain itu, diskusi antara dokter dan pasien juga penting untuk dilakukan, mengingat tujuan diselenggarakannya kegiatan tersebut adalah untuk memfasilitasi kebutuhan masyarakat atas jawaban dari permasalahan kesehatan mereka.

\section{d. Sikap Positif (Positiveness)}

Sikap positif adalah sikap yang memiliki perilaku positif yakni seseorang dapat berpikir secara positif terhadap diri sendiri dan orang lain. DeVito (2007:290) menyatakan bahwa sikap positif bisa dikomunikasikan paling tidak dengan dua cara, yaitu sikap dan dorongan. Jika sikap mengacu pada diri sendiri dan situasi komunikasi, dorongan mengacu pada sikap positif yang terdiri atas perilaku yang diharapkan selama komunikasi berlangsung. Tidak memotong pembicaraan adalah salah satu sikap positif yang diharapkan seseorang dari lawan bicaranya, sehingga dokter sebaiknya melakkan hal tersebut selama sesi 
konsultasi berlangsung. Penyampaian informasi menggunakan bahasa yang dipahami pasien juga penting. Seperti misalnya istilah umum kedokteran "kolesterol tinggi". Pada kenyataannya, tidak semua pasien paham betul tentang makna istilah tersebut. Selain itu, perhatian dokter juga menjadi salah satu sikap positif yang bisa ditunjukkan. Perhatian bisa dilakukan dengan banyak cara, salah satunya adalah dokter tidak melakukan kegiatan lain yang bisa menggangu jalannya sesi konsultasi, seperti bermain handphone, mengangkat telepon, atau kegiatan lainnya. Sikap positif, cepat dan tanggap dalam penanganan pasien melalui komunikasi di Whatsapp sangat membantu pasien, sehingga pasien dapat diberikan pertolongan pertama dalam keluhan penyakitnya.

\section{e. Kesetaraan (Equality)}

Keefektifan komunikasi interpersonal juga ditentukan oleh kesamaankesamaan yang dimiliki pelakunya. Seperti nilai, sikap, watak, perilaku, kebiasaan, pengalaman dan lain sebagainya. Konsultasi melalui media sosial Whatsapp tersebut membuat pasien merasa setara dengan konsultasi secara langsung dengan dokter, walaupun banyak keterbatasan dalam berintereaksi. Pasien dapat mengkomunikasikan keluhannya melalui Whastsapp.

Kepatuhan pasien terhadap saran medis yang diberikan oleh ahli medis juga sangat dipengaruhi oleh peran penting komunikasi kesehatan. Ada dua hal yang mempengaruhi kepatuhan pasien pada saran medis yang diterima, yakni :

1. Pasien harus terlebih dahulu memahami (understand) isu-isu kesehatan atau masalah-masalah kesehatan yang dihadapi. Untuk itu ia harus mampu menafsirkan dan memahami semua informasi kesehatan yang dikomunikasikan oleh tenaga medis pada dirinya.

2. Pasien harus mampu mengingat (memorize) saran medis yang diberikan. Bila dalam mengkomunikasikan informasi seputar kesehatan pasien, para ahli medis tidak menggunakan istilah (jargon) medis yang sulit dipahami oleh pasien umum dan informasi yang diberikan tidak terlalu banyak dan rumit, maka pasien dapat dengan mudah mengingat kembali semua informasi kesehatan (saran medis) yang telah disampaikan untuk dirinya. Misalnya, kapan minum obat tertentu dan berapa dosis untuk setiap obat dan sebagainya.

\section{PENUTUP \\ Kesimpulan}

Berdasarkan analisa yang telah dilakukan terhadap komunikasi interpersonal yang dilakukan antara dokter dengan pasien melalui media sosial Whatsapp, dapat ditarik kesimpulan sebagai berikut:

Komunikasi interpersonal melalui media sosial Whatsapp antara dokter dengan pasien di Klinik Medika Lestari dilakukan dengan mempertimbangkan keefektifan dalam berkomunikasi yaitu:

1. Keterbukaan, dokter memberikan keleluasaan kepada pasien untuk berkonsultasi, dan dokter memberikan solusi yang tepat dalam penganganan pertama untuk permasalahan kesehatan pasien.

2. Empati, Dokter berempati dengan cara memberikan perhatian khusus bagi pasien yang berkonsultasi memalaui Whatsapp, dokter bertanya mengenai keluhan-keluhan pasien, gejala-gejala yang dirasakan pasien, pertolongan pertama apa yang telah diberikan sebelum melakukan konsultasi, dan memberikan solusi terhadap penyakit yang diderita pasien bahkan memberikan resep obat kepada pasien. 
3. Sikap mendukung yaitu melakukan diskusi antara dokter dan pasien, mengingat tujuan diselenggarakannya program konsultasi melalui media sosial tersebut adalah untuk memfasilitasi kebutuhan masyarakat atas jawaban dari permasalahan kesehatan mereka.

4. Sikap positif, cepat dan tanggap dalam penanganan pasien melalui komunikasi di Whatsapp sangat membantu pasien, sehingga pasien dapat diberikan pertolongan pertama dalam keluhan penyakitnya.

5. Kesetaraan, Konsultasi melalui media sosial Whatsapp tersebut membuat pasien merasa setara dengan konsultasi secara langsung dengan dokter, walaupun banyak keterbatasan dalam berintereaksi.

\section{Saran}

Adapun saran yang dapat disampaikan dalam penelitian ini adalah Klinik Medika Lestari diharapkan dapat terus menjalin kedekatan dan komunikasi yang baik dengan para pasien, bukan hanya di klinik atau tatap muka tetapi juga melalui media sosial whattsapp yang disediakan klinik untuk berkonsultasi tetang kesehatan dan penyakit pasien, dengan begitu pasien akan lebih terbuka kepada dokter dan tidak ada keengganan untuk berkonsultasi.

\section{DAFTAR PUSTAKA}

Afriyadi, F. 2015. Efektivitas Komunikasi Interpersonal Antara Atasan dan Bawahan Karyawan PT Borneo Enterprisindo Samarinda. eJournal.ilkom.fisip-unmul.org , 362376.

Seta, A.K.. 1987. Konservasi Sumberdaya Tanah dan Air. Jakarta, Kalam Mulia.

Ardianto, E. 2011. Metodologi Penelitian Untuk Public Relations Kuantitatif dan Kualitatif. Bandung, Simbiosa Rekatama Media
Arikunto, S. 2010. Prosedur Penelitian Suatu Pendekatan Praktek. edisi revisi. Jakarta, PT. Rineka Cipta.

BPS. 2018. https://jakarta.bps.go.id/. Retrieved from https://jakarta.bps.go.id/: http://sp2010.bps.go.id/index.php/site ?id=3100000000\&wilayah $=$ DKIJakarta

Cangara, H. 1998. Pengantar Ilmu Komunikasi . Jakarta: PT Raja Grafindo Persada.

Canggara, H. 2004. Pengantar Ilmu Komunikasi. Jakarta: PT Raja Grafindo Persada.

DeVito, J. A. 2007. The Interpersonal Communication Book Edisi 11. Pearson Education, Inc.

Effendy, O. U. 2007. Ilmu Komunikasi Teori dan Praktek. Bandung: PT Remaja Rosdakarya.

Flew, T. 2008. New Media: An Introduction (3rd Edition). South Melbourne: Oxford University Press

Isparmo. 2018. http://isparmo.web.id. Retrieved from http://isparmo.web.id: http://isparmo.web.id/2016/11/21/data -statistik-pengguna-internetindonesia-2016/

Koentjaraningrat. 1993. Metode-metode Penelitian Masyarakat. (Edisi Ketiga). Jakarta, PT Gramedia Pustaka Utama.

Liliweri, A. 2008. Dasar-Dasar Komunikasi Kesehatan. Yogyakarta, Pustaka pelajar.

Moleong, L. 2007. Metode Penelitian Kualitatif. Bandung, Remaja Rosdakarya.

Notoatmodjo, S. 2005. Metodologi Penelitian Kesehatan. Jakarta, PT Rineka Cipta

Nugroho, Y. 2017. Intelektual Kebangsaan laporan dari Deputi II Kepala Staff Kepresidenan. Jakarta, Keuskupan Agung Jakarta.

Sugiyono. 2013. Metode Penelitian Pendidikan (Pendekatan Kuantitatif, Kualitatif dan R\&D). Bandung, Alfabeta. 
Sulisyo, dkk. 2006. Metode Penelitian . Jakarta, Wedatama Widya Sastra dan Fakultas Ilmu Pengetahuan Budaya Universitas Indonesia.
Widjaja, W. 2002. Komunikasi dan Hubungan Masyarakat. Jakarta, Bumi Aksara. 